\title{
PENGARUH PENDIDIKAN DAN PELATIHAN SERTA KECERDASAN EMOSIONAL TERHADAP KINERJA PEGAWAI PADA KANTOR KEJAKSAAN NEGERI PALU SULAWESI TENGAH
}

\author{
HASLINDA \\ IDRIS AZIS \\ BAKRI HASANUDDIN \\ Jurusan Manajemen, Fakultas Ekonomi, Universitas Tadulako \\ Email: Haslinda.anwar01@gmail.com
}

\begin{abstract}
This study aims to determine the influencet of education and training as well as emotional intelligence on the performance of employees at the State Attorney Office of Palu, Central Sulawesi. Sample consists of 31 people, who were selected with census method. Model of analysis multiple linear regressions with SPSS computer program for Windows Release 22.0. The research concludes that education and training (X1) and emotional intelligence (X2) simultaneously have significant influence on employee performance $(Y)$ in Attorney Office of Palu. This is evidenced by the F test that shows the significance value below 0.05 of 0.000. Education and training (X1) partially has significant influence on employee performance $(Y)$; this is evidenced by the t-test that shows significance value below 0.05 , of 0.001. Emotional intelligence (X2) partially has significant influence on employee performance $(Y)$, which is evidenced by the t-test that shows significance value below 0.05 of 0.000 .
\end{abstract}

Keywords: Education and Training, Emotional Intelligence, and Performance

\begin{abstract}
Abstrak
Penelitian ini bertujuan untuk mengetahui pengaruh pendidikan dan pelatihan serta kecerdasan emosional terhadap kinerja pegawai di Kejaksaan Negeri Palu, Sulawesi Tengah. Sampel dalam penomoran adalah 31 orang, metode pengambilan sampel menggunakan sampel jenuh atau sensus. Model analisis yang digunakan dalam penelitian ini adalah model analisis regresi berganda (multiple regression analysis) dengan bantuan program komputer SPSS for Windows Release 22.0.Analisis data menggunakan regresi linier berganda, uji $\mathrm{F}$ dan uji t. Hasil penelitian menyimpulkan bahwa pendidikan dan pelatihan (X1) dan emotional intelligence (X2) secara simultan berpengaruh signifikan terhadap kinerja karyawan (Y) pada Kejaksaan Negeri Palu. Hal ini dibuktikan dengan uji $\mathrm{F}$ yang menunjukkan nilai signifikansi kurang dari 0,05 adalah 0,000 . Pendidikan dan pelatihan (X1) berpengaruh secara parsial terhadap kinerja karyawan $(\mathrm{Y})$, hal ini dibuktikan dengan uji $\mathrm{t}$ yang menunjukkan nilai signifikansi kurang dari 0,05 yaitu 0,001. Kecerdasan Emosional (X2) berpengaruh secara parsial berpengaruh terhadap kinerja karyawan (Y), hal ini dibuktikan dengan uji $\mathrm{t}$ menunjukkan nilai signifikansi kurang dari 0,05 adalah 0,000.
\end{abstract}

Kata kunci: Pendidikan dan Pelatihan, Kecerdasan Emosional, dan Kinerja

\section{PENDAHULUAN}

\section{Latar Belakang Penelitian}

Standar personalia merupakan standar minimal yang harus dipenuhi agar seorang pegawai bisa mengerjakan pekerjaan-pekerjaannya dengan baik, disamping itu langkah selanjutnya untuk terus meningkatkan SDM yang terampil dan berkemampuan tinggi, adalah dengan memberikan pendidikan dan pelatihan terhadap setiap pelaku organisasi secara berkesinambungan dengan metode yang sistematis (Marlia, 2007).

Beberapa hal diatas menunjukkan belum efektifnya program diklat pada Kantor Kejasaan Negeri Palu ini, padalah diklat merupakan suatu program yang diharapkan dapat memberikan rangsangan/stimulus kepada seseorang untuk dapat meningkatkan kemampuan dalam pekerjaan tertentu, dan memperoleh pengetahuan umum dan pemahaman terhadap keseluruhan lingkungan kerja dan organisasi (Sofyandi, 2008).

Pencapaian kinerja pegawai secara optimal tidak dapat terwujud begitu saja hanya dengan mengikuti pendidikan dan pelatihan, akan tetapi harus didukung oleh faktor-faktor lain. Karena 
kemampuan dan kecapakan saja akan kurang berarti jika tidak diikuti oleh kecerdasan emosional (EQ) yang baik.

Kecerdasan mempunyai peran yang lebih besar dalam perjalanan karir, karena $80 \%$ kesuksesan seseorang dipengaruhi oleh kecerdasan lain seperti kecerdasan emoisonal yang bukan kecerdasan pikiran semata, tetapi juga dengan hati (Goleman, 2007).

Pencapaian kinerja yang tidak optimal juga sering kali disebabkan oleh kurangnya kemampuan pegawai dalam pengelolaan kecerdasan emosional (EQ). Goleman (2007) memaparkan bahwa Kecerdasan Emosional (EQ) mempunyai lima komponen, tiap komponen mempunyai beberapa kompetensi. Kelima komponen Kecerdasan Emosional (EQ) yang dimaksud yaitu; mengenali emosi diri, mengelola emosi, memotivasi diri sendiri, mengenali emosi orang lain, dan membina hubungan.

\section{Permasalahan Penelitian}

Berdasarkan latar belakang di atas, maka rumusan masalah yang akan penulis ajukan adalah:

1. Apakah Pendidikan dan Pelatihan serta Kecerdasan Emosional secara bersama-sama berpengaruh signifikan terhadap Kinerja Pegawai Pada Kantor Kejaksaan Negeri Palu?

2. Apakah Pendidikan dan Pelatihan secara parsial berpengaruh signifikan terhadap Kinerja Pegawai Pada Kantor Kejaksaan Negeri Palu?

3. Apakah Kecerdasan Emosional secara parsial berpengaruh signifikan terhadap Kinerja Pegawai Pada Kantor Kejaksaan Negeri Palu?

\section{Tujuan Penelitian}

Adapun tujuan dari penelitian ini adalah sebagai berikut:

1. Deskripsi hasil analisis pengaruh pendidikan dan pelatiahan serta kecerdasan emosional secara bersama-sama berpengaruh signifikan terhadap Kinerja Pegawai Pada Kantor Kejaksaan Negeri Palu?

2. Deskripsi hasil analisis pengaruh pendidikan dan pelatihan secara parsial berpengaruh signifikan terhadap Kinerja Pegawai Pada Kantor Kejaksaan Negeri Palu.

3. Deskripsi hasil analisis pengaruh kecerdasan emosional secara parsial berpengaruh signifikan terhadap Kinerja Pegawai Pada Kantor Kejaksaan Negeri Palu?

\section{KAJIAN LITERATUR DAN PENGEMBANGAN HIPOTESIS Pengertian Pendidikan dan Pelatihan}

Pendidikan adalah situasi dimana terjadi dialog antara peserta didik dengan pendidik, yang memungkinkan peserta didik tumbuh kearah yang dikehendaki oleh pendidik, agar selaras dengan nilai-nilai yang dijunjung tinggi masyarakat. Satori (2007). Pelatiah adalah salah satu usaha untuk mengembangkan SDM, terutama dalam hal Pengetahuan (Knowledge), Kemampuan (Ability), Keahlian (Skill) dan Sikap (Attitude) yang untuk selanjutnya disebut KASAt (Arep \& Tanjung, 2002).

\section{Pengertian Kecerdasan Emosional (EQ)}

Menurut Goleman (2007), "kecerdasan emosional (EQ) adalah kemampuan untuk mengenali emosi dalam diri sendiri dan diri orang lain secara efektif dapat mengendalikan emosi tersebut dengan baik". Lebih lanjut, Goleman menyatakan bahwa kontribusi IQ bagi keberhasilan seseorang hanya sekitar 20\% dan sisanya 80\% ditentukan oleh faktor-faktor Kecerdasan Emosional.

\section{Pengertian Kinerja}

Menurut Mangkunegara (2013), kinerja (prestasi kerja) adalah hasil kerja secara kualitas dan kuantitas yang dicapai oleh seorang pegawai dalam melaksanakan tugasnya sesuai dengan tanggung jawab yang diberikan kepadanya.

\section{METODE PENELITIAN Metode Pengumpulan Data}

Dalam penelitian ini, teknik pengumpulan data yang dilakukan untuk mengukur variabelvariabel yang diteliti sebagai berikut: 
1. Pemangamatan/Observasi

Berdasarkan pengamatan/observasi, peneliti mendapatkan fenomena yang berkaitan dengan perilaku karyawan dalam bekerja, bagaimana hubungan antar sesama karyawan di Kantor Kejaksaan Negeri Palu serta bagaimana karyawan mengelola kecerdasan emosional mereka.

2. Wawancara

Dalam wawancara ini peneliti mendapatkan informasi-informasi yang berkaitan dengan variabel penelitian misalnya bagaimana pendidikan dan pelatihan, serta kecerdasan emosional yang ada pada pegawai Kantor Kejaksaan Negeri Palu.

3. Kuesioner

Merupakan instrument pengumpulan data primer dengan cara mengedarkan daftar pertanyaan kepada responden yang menjadi objek penelitian ini, yaitu pegawai pada Kantor Kejaksaan Negeri Palu.

\section{Dokumentasi}

Dilakukan dengan mengumpulkan data dan penelusuran dokumen baik berupa tulisan maupun data-data tentang perusahaan yang telah dipublikasikan dan relevan dengan topik penelitian, berupa data sejarah singkat, struktur, visi dan misi serta jumlah pegawai pada Kantor Kejaksaan Negeri Palu.

\section{Definisi Operasional Variabel}

Adapun dalam penelitian ini variabel terbagi dalam dua bagian yaitu variabel independen atau bebas (X) dan variabel dependen atau tidak bebas (Y). Dimana variabel bebasnya adalah Pendidikan dan Pelatihan (diklat), serta Kecerdasan Emosional (EQ) dan variabel tidak bebasnya adalah Kinerja.

\section{Pengujian Instrumen Penelitian Uji Validitas}

Suatu skala pengukuran dikatan valid bila terdapat kesamaan antara data yang terkumpul dengan data yang sesungguhnya terjadi pada objek penelitian. Selanjutnya valid berarti instrument tersebut dapat digunakan untuk mengukur apa yang seharunya diukur Sugiyono (2009).

Selanjutnya peneliti menentukan validitasnya dengan menggunakan bantuan SPSS 22. berdasarkan formula tertentu, diantaranya koefisien korelasi product moment dari karl person, yaitu :

$$
r_{x y}=\frac{N \sum X Y-\left(\sum X\right)\left(\sum Y\right)}{\sqrt{\left[N \sum X^{2}-\left(\sum X\right)^{2}\right]\left[N \sum Y^{2}-\left(\sum Y\right)^{2}\right]}}
$$

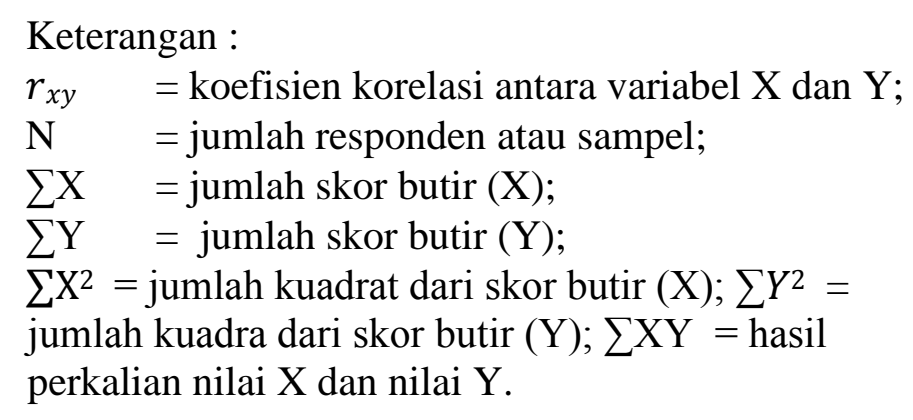

\section{Uji Realibilitas}

Sugiyono (2009), menyatakan bahwa instrument yang reliabel adalah instrument yang bila digunakan beberapa kali untuk mengukur obyek yang sama, akan menghasilkan data yang sama. Formula yang dipergunakan untuk menguji relialibilas instrument dalam penelitian ini adalah koefisien alpha $(\alpha)$ dari Cronbach, yaitu: 


$$
r_{11}=\left(\frac{k}{(k-1)}\right)\left(1-\frac{\Sigma \sigma_{t}^{2}}{\sigma_{t}^{2}}\right)
$$

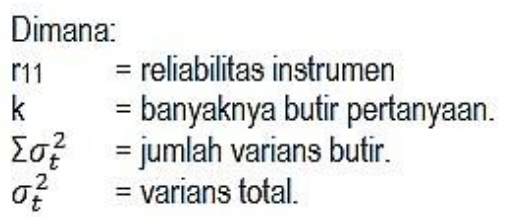

\section{Uji Asumsi Klasik}

Masalah-masalah dalam pengujian model regresi dalam penelitian ini dapat menggunakan bentuk model pengujian klasik.

\section{Uji Normalitas Data}

Normalitas bertujuan menguji apakah dalam sebuah model regresi, variabel dependen (terikat), variebel independen (bebas) atau keduanya mempunyai distribusi normal ataukah tidak.

\section{Uji Multikolinieritas}

Uji Multikolinieritas berguna untuk mengetahui apakah pada model regeresi yang diajuka telah ditemukan korelasi yang kuat antarvaribel independen. Jika terjadi koralasi yang kuat, terdapat masalah multikolineritas yang harus diatasi (Umar, 2002).

\section{Uji Heterokedastistas}

Uji heteroskedastisitas dilakukan untuk mengetahui apakah dalam sebuah model regresi terjadi ketidaksamaan varians dari residual suatu pengamatan ke pemangatan lain.

\section{HASIL DAN PEMBAHASAN}

\section{Deskripsi Berdasarkan Karakteristik Responden}

Karakteristik responden pegawai pada Kantor Kejaksaan Negeri Palu Sulawesi Tengah akan diuraikan dalam aspek jenis kelamin, pendidikan terakhir pegawai, usia dan lama bekerja pegawai. Dari 31 (tiga puluh satu) kuesioner yang dibagikan semua jawabannya lengkap dan layak digunakan untuk dianalisis. Di bawah ini akan dipaparkan karakteristik responden pegawai Kantor Kejaksaan Negeri Palu Sulawesi Tengah.

\section{Jenis Kelamin}

Hasil penelitian yang dilakukan dengan jumlah responden berdasarkan jenis kelamin sebagaimana terlihat pada Tabel 1 berikut:

Tabel 1. Jenis Kelamin Responden Kantor Kejaksaan Negeri Palu Sulawesi Tengah

\begin{tabular}{ccc}
\hline Jenis Kelamin & Responden & Persentase \\
\hline Pria & 15 & $48 \%$ \\
Wanita & 16 & $52 \%$ \\
Jumlah & 31 Orang & $100 \%$ \\
\hline
\end{tabular}

Berdasarkan Tabel 1 di atas, terlihat bahwa jumlah pegawai pria dan wanita tidak berbeda jauh, hal ini memberikan makna bahwa Kantor Kejaksaan Negeri Palu tidak melihat jenis kelamin dalam menerima pegawai, tetapi lebih obyektif yaitu berdasarkan hasil seleksi rekruitmen pegawai. 


\section{Pendidikan Terakhir}

Hasil penelitian ini, pengamatan dan dokumentasi yang dilakukan dengan jumlah responden sebesar 31 orang, diperoleh karakteristik responden berdasarkan pendidikan terakhir, sebagaimana terlihat dalam tabel berikut:

Tabel 2. Pendidikan Terakhir Responden Pegawai Kantor Kejaksaan Negeri Palu

\begin{tabular}{ccc}
\hline Status & Responden & Persentase \\
\hline SLTA & 5 & $16 \%$ \\
D3 & 3 & $10 \%$ \\
S1 & 21 & $68 \%$ \\
S2 & 2 & $6 \%$ \\
S3 & & \\
Jumlah & 31 & $100 \%$ \\
\hline
\end{tabular}

Hasil penelitian yang dilakukan, diperoleh data karakteristik responden berdasarkan pendidikan terakhir sebagaiman terlihat dalam Tabel 2, dimana dari pengelompokan responden berdasarkan pendidikan terakhir menunjukkan bahwa pegawai Kantor Kejaksaan Negeri Palu yang pendidikan terakhirnya SLTA lebih banyak dibandingkan D3. Hal ini disebabkan karena pegawai yang berpendidikan SLTA banyak diperlukan untuk mengisi jabatan yang tidak memerlukan pendidikan yang lebih tinggi atau keterampilan khusus seperti jabatan administrasi, surat masuk, sekretaris dan kurir. Sedangakn responden yang pendidikan terakhirnya D3 berkeja pada bagian computer, sisanya didominan oleh pendidikan terakhirnya S1 sebanyak 21 orang $(68 \%)$.

\section{Usia Pegawai}

Hasil Penelitian dilakukan dengan jumlah 31 responden diperoleh karakteristik responden berdasarkan usia pegawai Kantor Kejaksaan Negeri Palu Sulteng sebagaiamana yang terlihat pada Tabel 3 di bawah ini :

Tabel 3.Usia Pegawai Kantor Kejaksaan Negeri Palu

\begin{tabular}{ccc}
\hline Usia Pegawai & Responden & Persentase \\
\hline 22-25 Tahun - - 26-29 Tahun 6 $19 \%$ & \\
30-35 Tahun & 7 & $23 \%$ \\
Diatas 35 Tahun & 18 & $58 \%$ \\
Jumlah & 31 & $100 \%$
\end{tabular}

Berdasarkan data Tabel 3 diatas, menunjukkan bahwa pegawai Kantor Kejaksaan Negeri Palu lebih banyak berusia diatas 35 tahun. Hal ini memberi makna bahwa instansi ini memiliki pegawai yang dan sudah berpelangalaman dan menguasai dibidang pekerjaannya.

\section{Masa Kerja}

Hasil penelitian yang dilakukan dengan jumlah 31 Responden diperoleh karakteristik responden berdasarkan masa kerja pegawai Kantor Kejaksaan Negeri Palu sebagaiamana yang terlihat pada Tabel 4 di bawah ini: 
Tabel 4. Masa Kerja Pegawai Kantor Kejaksaan Negeri Palu Sulteng

\begin{tabular}{ccc}
\hline Masa Kerja & Responden & Persentase \\
\hline 1-2 Tahun & 2 & $7 \%$ \\
3-5 Tahun & & \\
6-10 Tahun & 10 & $32 \%$ \\
Diatas 10 tahun & 19 & $61 \%$ \\
Jumlah & 31 & $100 \%$ \\
\hline
\end{tabular}

Berdasarkan Tabel 4 di atas dapat diketahui bahwa pegawai Kantor Kejaksaan Negeri Palu, dominan masa kerjanya di atas 10 tahun, hal ini memberikan makna bahwa, pegawai Kantor Kejaksaan Negeri Palu memiliki pegawai yang berpengalaman dalam bekerja.

Hasil Pengujian Instrument Penelitian Pengujian instrumen penelitian terdiri dari uji kesahihan (uji validitas) dan uji keandalan (uji reabilitias).

\section{Hasil Uji Validitas}

Kemampuan indikator mengukur variabelnya dianalisis dengan menggunakan uji validitas. Suatu skala pengukuran dikatakan valid bila terdapat kesamaan antara data yang terkumpul dengan data yang sesungguhnya terjadi pada objek penelitian.

Selanjutnya valid berarti instrumen tersebut dapat digunakan untuk mengukur apa yang seharusnya diukur, Sugiyono (2009). Sebuah instrumen dikatakan valid apabila memiliki koefisien korelasi (corrected item total correlation) $\geq 0,3$, sebaliknya apabila koefiesien korelasi $\leq 0,3$ maka dikatakan tidak valid.

Hasil penelitian untuk uji validitas pada masing-masing variabel penelitian menggunakan 20 responden pada Kantor Polresta Palu Sulawesi Tengah, dengan memakai progam SPSS 22 seperti dibawah ini :

\section{Pendidkan dan Pelatihan}

Pendidikan dan Pelatihan merupakan variabel independen pertama yang diteliti dan diwakili dengan 25 (dua puluh lima) item pernyataan yang diajukan dalam kuesioner peneltian. Hasil uji validitas dapat dilihat pada Tabel 5 berikut ini:

Tabel 5. Hasil Pengujian Validitas Variabel Pendidikan Dan Pelatihan (X1)

\begin{tabular}{cccccc}
\hline Indikator Penelitian & item pernyatan & & r-hitung & \multicolumn{2}{r}{ r-kritis Status Item } \\
\hline & Pendidikan dan X1.1 & 0,419 & 0,3 & Valid & \\
Pelatihan & X1.2 & 0,574 & 0,3 & Valid & \\
& & & & & \\
\hline & & & & & \\
\hline & X1.3 & 0,435 & 0,3 & Valid \\
& X1.4 & 0,615 & 0,3 & Valid \\
X1.5 & 0,648 & 0,3 & Valid \\
\hline Metode Pendidikan dan & X1.6 & 0,381 & 0,3 & Valid \\
Pelatihan & X1.7 & 0,506 & 0,3 & Valid \\
& X1.8 & 0,403 & 0,3 & Valid \\
& X1.9 & 0,326 & 0,3 & Valid \\
& X1.10 & 0,515 & 0,3 & Valid \\
\hline
\end{tabular}




\begin{tabular}{ccccc}
\hline & X1.11 & 0,468 & 0,3 & Valid \\
& X1.12 & 0,739 & 0,3 & Valid \\
Sikap dan & X1.13 & 0,633 & 0,3 & Valid \\
Keterampilan Instruktur & X1.14 & 0,663 & 0,3 & Valid \\
& X1.15 & 0,602 & 0,3 & Valid \\
\hline \multirow{3}{*}{ Lama Waktu Diklat } & X1.16 & 0,638 & 0,3 & Valid \\
& X1.17 & 0,739 & 0,3 & Valid \\
& X1.18 & 0,422 & 0,3 & Valid \\
& X1.20 & 0,735 & 0,3 & Valid \\
Xasilitas/Sarana & 0,524 & 0,3 & Valid \\
& X1.21 & 0,257 & 0,3 & Tidak Valid \\
& X1.23 & 0,557 & 0,3 & Valid \\
& X1.24 & 0,474 & 0,3 & Valid \\
X1.25 & 0,677 & 0,3 & Valid \\
& 0,146 & 0,3 & Tidak Valid
\end{tabular}

Berdasarkan hasil uji validitas yang telah dilakukan, diketahui bahwa dari 25 item pernyataan terdapat 2 item pernyataan yang tidak valid yaitu X1.21 dan X1.25, karena nilai r-hitungnya dibawah 0,3 . Untuk itu 23 item pernyataan yang tersisa merupakan instrumen yang layak (sahih) diikutsertakan dalam penelitian ini, karena koefisien korelasi (r-hitung) item pernyataan tersebut telah diuji kevaliditannya dan memperoleh lebih dari 0,3 atau lebih besar dari nilai r-kritis (Sugiyono, 2010: 179).

\section{Kecerdasan Emosional}

Kecerdasan Emosional merupakan variabel independen kedua yang diteliti dan diwakili dengan 25 item pernyataan yang diajukan dalam kuesioner penelitian. Hasil uji validitas dapat dilihat pada tabel berikut ini:

Tabel 6. Hasil Uji Validitas Variabel Kecerdasan Emosional (X2)

\begin{tabular}{ccccc}
\hline Indikator Penelitian & item pernyataan & r-hitung & r-kritis & Status Item \\
\hline \multirow{3}{*}{ Mengenali Emosi Diri } & X2.1 & 0,414 & 0,3 & Valid \\
& X2.2 & 0,399 & 0,3 & Valid \\
& X2.3 & 0,351 & 0,3 & Valid \\
\hline & & & & \\
\hline & X2.4 & 0,371 & 0,3 & Valid \\
& X2.5 & 0,386 & 0,3 & Valid \\
\hline X2.6 & 0,543 & 0,3 & Valid \\
X2.7 & 0,434 & 0,3 & Valid \\
X2.8 & 0,220 & 0,3 & Tidak \\
& X2.9 & 0,148 & 0,3 & Tidak
\end{tabular}




\begin{tabular}{ccccc} 
& & & & Valid \\
& X2.10 & 0,434 & 0,3 & Valid \\
\hline & X2.11 & 0,534 & 0,3 & Valid \\
& X2.12 & 0,510 & 0,3 & Valid \\
Memotivasi Diri Sendiri & X2.13 & 0,085 & 0,3 & Tidak \\
& X2.14 & 0,532 & 0,3 & Valid \\
& X2.15 & 0,480 & 0,3 & Valid \\
Mengenali Emosi Orang & X2.16 & 0,588 & 0,3 & Valid \\
Lain & X2.17 & 0,653 & 0,3 & Valid \\
& X2.18 & 0,573 & 0,3 & Valid \\
& X2.20 & 0,642 & 0,3 & Valid \\
& X2.21 & 0,492 & 0,3 & Valid \\
\hline X2.22 & 0,470 & 0,3 & Valid \\
X2.23 & 0,768 & 0,3 & Valid \\
X2.24 & 0,415 & 0,3 & Valid \\
X2.25 & 0,649 & 0,3 & Valid \\
& & 0,700 & 0,3 & Valid \\
\hline
\end{tabular}

Berdasarkan hasil uji validitas yang telah dilakukan, diketahui bahwa terdapat 3 item pernyataan yang tidak valid X2.8, X2.9 dan X2.13 karena nilai r-hitungnya dibawah 0,3. Untuk itu 22 item pernyataan yang tersisa merupakan instrumen yang layak (sahih) diikutsertakan dalam penelitian ini, karena koefisien korelasi (r-hitung) item pernyataan tersebut telah diuji kevaliditannya dan memperoleh lebih dari 0,3 atau lebih besar dari nilai r-kritis (Sugiyono, 2009).

\section{$\operatorname{Kinerja}(Y)$}

Kinerja merupakan variabel dependen yang diteliti dan diwakili dengan 15 item pernyataan yang diajukan dalam kuesioner penelitian. Hasil uji validitas dapat dilihat pada tabel berikut ini:

Tabel 7. Hasil Pengujian Validitas Variabel Kinerja (Y)

\begin{tabular}{ccccc}
\hline Indikator Penelitian & item pernyataan & r-hitung & r-kritis & Status Item \\
\hline \multirow{2}{*}{ Usaha (Effort) } & Y1.1 & 0,366 & 0,3 & Valid \\
\cline { 2 - 5 } & Y1.2 & 0,767 & 0,3 & Valid \\
& Y1.3 & 0,840 & 0,3 & Valid \\
& Y1.4 & 0,564 & 0,3 & Valid \\
Kemampuan & Y1.5 & 0,582 & 0,3 & Valid \\
(Abilities) & Y1.6 & 0,448 & 0,3 & Valid \\
& Y1.7 & 0,521 & 0,3 & Valid \\
& Y1.8 & 0,598 & 0,3 & Valid \\
& Y1.9 & 0,496 & 0,3 & Valid
\end{tabular}




\begin{tabular}{ccccc} 
& Y1.10 & 0,700 & 0,3 & Valid \\
& Y1.11 & 0,588 & 0,3 & Valid \\
& Y1.12 & 0,469 & 0,3 & Valid \\
Persepsi Tugas & Y1.13 & 0,669 & 0,3 & Valid \\
& Y1.14 & 0,524 & 0,3 & Valid \\
& Y1.15 & 0,644 & 0,3 & Valid \\
\hline
\end{tabular}

Berdasarkan hasil uji validitas yang telah dilakukan diketahui bahwa semua item pernyataan untuk kinerj (Y) dalam kuesioner yang digunakan pada penelitian ini adalah valid. 15 item pernyataan layak (sahih) diikutsertakan dalam penelitian ini, karena koefisien korelasi (r-hitung) yang diperoleh lebih besar dari 0,3 atau lebih besar dari nilai r-krits (Sugiyono, 2009).

\section{Hasil Uji Realibilitas}

Setelah seluruh instrument dalam penelitian ini dinyatakan valid, maka selanjutnya perlu dilakukan pengujian realibilitas untuk menguji keandalan instrumen penelitian. Uji realibilitas ini dilakukan terhadap pernyataan-pernyataan yang sudah valid untuk mengetahui sejauh mana hasil pengukuran tetap konsisten bila dilakukan pengukuran kemabali dengan gejala yang sama.

Uji realibilitas dalam penelitian in menggunakan bantuan software SPSS 22 for windows dengan uji statistic Cronbanch Alpha $(\alpha)$. Suatu variabel dinyatakan realibel jika memberikan nilai Cronbach Alpha > 0,60. Berdasarkan hasil pengujian realibilitas, keseluruhan variabel penelitian diketahui masing-masing mempunyai alpha Cronbach sebagaiaman yang tampak dalam Tabel 8 berikut :

Tabel 8. Hasil Uji Realibilitas Instrumen Penelitian

\begin{tabular}{ccc}
\hline Variabel & Cronbach's Alpha & Keterangan \\
\hline Pendidikan dan Pelatihan & .913 & Reliabel \\
Kecerdasan Emosional & .888 & Reliabel \\
Kinerja & .899 & Reliabel \\
\hline
\end{tabular}

Berdasarkan pada Tabel diatas, tampilan output SPSS menunjukkan bahwa nilai Cronbach's Alpha > 0,60 yang menurut kriteria Nunnaly bisa dikatakan reliabel, sehingga dapat disimpulkan bahwa semua item pernyataan dari variabel X1, X2, dan Y dapat diuji lebih lanjut.

\section{Hasil Uji Asumsi Klasik}

Uji asumsi klasik digunakan dengan maksud untuk mengevaluasi terhadap model regresi linear berganda yang digunakan, apakah menghasilkan nilai yang ideal atau apakah memenuhi asumsi klasik atau tidak.

Uji asumsi klasik yang digunakan dalam penelitian ini menggunakan alat bantu SPSS for windows versi 22.

\section{Deskripsi Variabel Pendidikan dan Pelatihan (X1)}

Pendidikan dan pelatihan adalah proses belajar mengajar dalam rangka meningkatkan kemampuan sumber daya manusia dalam melaksanakan tugasnya. Hasil kuesioner dari pendidikan dan pelatihan yang diajukan kepada responden memberikan gambaran bahwa pendidikan dan pelatihan pegawai Kantor Kejaksaan Negeri Palu memiliki frekuensi berbeda-berbeda ditinjau dari indikator pendidikan dan pelatihan yang terdiri dari isi materi yang diajarkan, metode diklat, sikap dan keterampilan instruktur, lama waktu diklat, dan fasilitas/sarana. 

berikut ini :

Tanggapan setiap pernyataan dari variabel pendidikan dan pelatihan dapat dilihat pada Tabel Tabel 9. Tanggapan Responden Variabel Pendidikan dan Pelatihan

\begin{tabular}{|c|c|c|c|c|c|c|c|c|c|c|}
\hline & \multirow{2}{*}{ Items } & \multirow{2}{*}{ Ket. } & \multicolumn{5}{|c|}{ Kategori Jawaban } & \multirow{2}{*}{ Total } & \multirow{2}{*}{ Skor } & \multirow{2}{*}{ Mean } \\
\hline & & & SS & $\mathrm{s}$ & RG & TS & STS & & & \\
\hline \multirow{9}{*}{$\begin{array}{c}\text { Isi/materi } \\
\text { pendidikan } \\
\text { dan pelatihan }\end{array}$} & $\begin{array}{l}\text { Materi menunjang } \\
\text { pekerjaan }\end{array}$ & $\begin{array}{c}\text { Frek. } \\
\%\end{array}$ & $\begin{array}{c}19 \\
61,3 \%\end{array}$ & $\begin{array}{c}12 \\
38.7 \%\end{array}$ & - & - & - & $\begin{array}{c}31 \\
100 \%\end{array}$ & 143 & 4,61 \\
\hline & $\begin{array}{l}\text { pekerjaan } \\
\text { Peningkatkan }\end{array}$ & Frek. & $\begin{array}{c}61,3 \% \\
19\end{array}$ & 12 & - & - & - & $\begin{array}{c}100 \% \\
31\end{array}$ & & \\
\hline & keterampilam & $\%$ & $61,3 \%$ & $38,7 \%$ & - & - & - & $100 \%$ & 143 & 4,61 \\
\hline & Meningkatkan & Frek. & 15 & 16 & - & - & - & 31 & & \\
\hline & pengetahuan & $\%$ & $48,4 \%$ & 51,6 & - & - & - & $100 \%$ & 139 & 4,48 \\
\hline & Materi Up to date & Frek. & 8 & 19 & 4 & - & - & 31 & 128 & 4,13 \\
\hline & & $\%$ & $25,8 \%$ & $61,3 \%$ & $12,9 \%$ & - & - & $100 \%$ & & \\
\hline & Kebutuhan tugas & $\begin{array}{c}\text { Frek. } \\
\%\end{array}$ & $\begin{array}{c}14 \\
45,2 \%\end{array}$ & $\begin{array}{c}17 \\
54,8 \%\end{array}$ & - & - & - & $\begin{array}{c}31 \\
100 \%\end{array}$ & 138 & 4,45 \\
\hline & \multicolumn{9}{|c|}{ Mean indikator isi/materi pendidikan dan pelatihan } & 4,46 \\
\hline \multirow{8}{*}{$\begin{array}{c}\text { Metode } \\
\text { pendidikan } \\
\text { dan pelatihan }\end{array}$} & $\begin{array}{c}\text { Subjek yang } \\
\text { diajarkan }\end{array}$ & $\begin{array}{l}\text { Frek. } \\
\%\end{array}$ & $\begin{array}{c}13 \\
41,9 \%\end{array}$ & $\begin{array}{c}17 \\
54,8 \%\end{array}$ & $\begin{array}{c}1 \\
3,2 \%\end{array}$ & $\begin{array}{l}- \\
-\end{array}$ & - & $\begin{array}{c}31 \\
100 \%\end{array}$ & 136 & 4,39 \\
\hline & Gaya belajar & Frek. & 6 & 21 & 4 & - & - & 31 & 126 & 4.06 \\
\hline & Gay d verajal & $\%$ & $19,4 \%$ & $67,7 \%$ & $12,9 \%$ & - & - & $100 \%$ & 120 & 4,00 \\
\hline & Mudah dimengerti & Frek. & 12 & 19 & - & - & - & 31 & 136 & 4,39 \\
\hline & Meningkatkan & $\begin{array}{c}\% \\
\text { Frek. }\end{array}$ & $\begin{array}{c}38,7 \% \\
16\end{array}$ & $\begin{array}{l}61,3 \% \\
15\end{array}$ & - & - & - & $\begin{array}{c}100 \% \\
31\end{array}$ & & \\
\hline & komunikasi & $\%$ & $51,6 \%$ & $48,4 \%$ & - & - & - & $100 \%$ & 140 & 4,52 \\
\hline & Menarik minat & $\begin{array}{c}\text { Frek. } \\
\%\end{array}$ & $\begin{array}{c}10 \\
32,3 \%\end{array}$ & $\begin{array}{c}17 \\
54.8 \%\end{array}$ & $12.9 \%$ & - & - & $\begin{array}{c}31 \\
100 \%\end{array}$ & 130 & 4,19 \\
\hline & \multicolumn{9}{|c|}{ Mean indikator metode pendidikan dan pelatihan } & 4,31 \\
\hline \multirow{10}{*}{$\begin{array}{l}\text { Sikap dan } \\
\text { keterampilan } \\
\text { instruktur }\end{array}$} & Menguasai materi & $\begin{array}{c}\text { Frek. } \\
\%\end{array}$ & $\begin{array}{c}13 \\
419 \%\end{array}$ & $\begin{array}{c}17 \\
548 \%\end{array}$ & 13 & - & - & $\begin{array}{c}31 \\
100 \%\end{array}$ & 136 & 4,39 \\
\hline & & Frek. & $\begin{array}{c}41,9 \% \\
9\end{array}$ & $\begin{array}{c}34,8 \% \\
20\end{array}$ & $\frac{3,2 \%}{2}$ & - & - & $\begin{array}{l}100 \% \\
31\end{array}$ & & \\
\hline & Memotivasi peserta & $\%$ & $29,0 \%$ & $64,5 \%$ & $6,5 \%$ & - & - & $100 \%$ & 131 & 4,23 \\
\hline & & Frek. & 11 & 20 & - & - & - & 31 & & \\
\hline & Mengetanui tujuan & $\%$ & $35,5 \%$ & $64,5 \%$ & - & - & - & $100 \%$ & 135 & 4,35 \\
\hline & Menghilangkan rasa & Frek. & 6 & 20 & 5 & - & - & 31 & 125 & \\
\hline & takut & $\%$ & $19,4 \%$ & $64,5 \%$ & $16,1 \%$ & - & - & $100 \%$ & 123 & 4,03 \\
\hline & Keterampilan & Frek. & 11 & 18 & 2 & - & - & 31 & & \\
\hline & instruktur & $\%$ & $35,5 \%$ & $58,0 \%$ & $6,5 \%$ & - & - & $100 \%$ & 133 & 29 \\
\hline & \multicolumn{9}{|c|}{ Mean indikator sikap dan keterampilan instruktru } & 4,26 \\
\hline \multirow{9}{*}{$\begin{array}{l}\text { Lama waktu } \\
\text { diklat }\end{array}$} & Kreativitas & $\begin{array}{c}\text { Frek. } \\
\%\end{array}$ & $\begin{array}{c}5 \\
16.1 \%\end{array}$ & $\begin{array}{c}23 \\
74.2 \%\end{array}$ & $\begin{array}{l}3 \\
9.7 \%\end{array}$ & - & - & 31 & 126 & 4,06 \\
\hline & Lamanya waktu & Frek. & 8 & 20 & 3 & - & - & 31 & & \\
\hline & diklat & $\%$ & $25,8 \%$ & $64,5 \%$ & $9,7 \%$ & - & - & $100 \%$ & 129 & 4,16 \\
\hline & Durasi materi & Frek. & 3 & 26 & 2 & - & - & 31 & & \\
\hline & Durası mater1 & $\%$ & $9,7 \%$ & $83,9 \%$ & $6,5 \%$ & - & - & $100 \%$ & 123 & 4,03 \\
\hline & Waktu sudah efektif & Frek. & $\begin{array}{c}5 \\
16 \\
16\end{array}$ & $\begin{array}{c}22 \\
710 \%\end{array}$ & $12 \stackrel{4}{9} \%$ & - & - & $\begin{array}{c}31 \\
100 \%\end{array}$ & 125 & 4,03 \\
\hline & & Frek. & 5 & 23 & 3 & - & - & 31 & & \\
\hline & Waktu istirahat & $\%$ & $16,1 \%$ & $74,2 \%$ & $9,7 \%$ & - & - & $100 \%$ & 126 & 4,06 \\
\hline & \multicolumn{9}{|c|}{ Mean indikator lama waktu diklat } & 4,07 \\
\hline \multirow{7}{*}{$\begin{array}{c}\text { Fasilitas/ } \\
\text { sarana. }\end{array}$} & Peralatan yang layak & Frek. & 12 & 19 & - & - & - & 31 & 136 & 4,38 \\
\hline & & $\%$ & $38,7 \%$ & $61,3 \%$ & - & - & - & $100 \%$ & 150 & \\
\hline & Pendingin ruangan & $\begin{array}{c}\text { Frek. } \\
\%\end{array}$ & $\begin{array}{c}12 \\
38.7 \%\end{array}$ & $\begin{array}{c}17 \\
548 \%\end{array}$ & 6.2 & - & - & $\begin{array}{c}31 \\
100 \%\end{array}$ & 134 & 4,32 \\
\hline & Penerangan yang & Frek. & 14 & 17 & - & - & - & 31 & & \\
\hline & \multirow{2}{*}{\multicolumn{9}{|c|}{ Mean indikator fasilitas/sarana }} & 4,45 \\
\hline & & & & & & & & & & 4,38 \\
\hline & \multicolumn{9}{|c|}{ Mean Variabel Pendidikan dan Pelatihan } & 4,30 \\
\hline
\end{tabular}

Dari tabel di atas dapat diketahui bahwa tanggapan responden untuk indikator isi materi pendidikan dan pelatihan menujukkan presentase yang mengindikasikan rata-rata responden menjawab setuju, berkisar 38,7\%-61,3\%. Hal ini dapat diartikan bahwa, pegawai Kantor Kejaksaan Negeri Palu setuju dengan isi materi yang diajarkan dalam diklat, terutama untuk pernyataan yang berhubungan dengan adanya "materi yang menunjung pekerjaan" dan "peningkatan keterampilan" dengan mean terbesar yaitu, 4,61. Hal ini menandakan bahwa responden menyadari adanya peningkatan pengetahuan yang dapat menujuang pekerjaan serta peningkatan keterampilan komunikasi dan sikap mereka setelah mengikut pendidikan dan pelatihan.

Sementara untuk total rata-rata keseluruhan nilai mean dari variabel pendidikan dan pelatihan adalah 4,30. Berdasarkan interprestasi nilai mean berada pada nilai 4,07-4,46 hal ini memberi makna bahwa tanggapan responden terhadap variabel pendidikan dan pelatihan sangat baik atau sangat penting. Artinya, responden yang merupakan pegawai pada kantor kejaksaan negeri palu beranggapan bahwa indikator-indikator dalam penilaian variabel pendidikan dan pelatihan mulai dari isi/materi diklat, metode diklat, sikap dan keterampilan instruktur, lama waktu diklat, serta fasilitas dan sarana yang dirasakan oleh pegawai dalam mengikuti diklat dinilai sudah baik dan memadai. 
Deskripsi Variabel Kecerdasan Emosional (X2)

Hasil kuesioner dari kecerdasan emosional yang diajukan kepada responden memberikan gambaran bahwa kecerdasan emosional pegawai Kantor Kejaksaan Negeri Palu memiliki freskuensi yang berbeda-beda ditinjau dari indikator kecerdasan emosional yang terdiri dari mengenali emosi diri, mengelola emosi, memotivasi diri sendiri, mengenali emosi orang lain, dan membina hubungan.

Tanggapan setiap pernyataan dari variabel kecerdasan emosional dapat dilihat pada Tabel berikut ini:

Tabel 1 0. Tanggapan Responden Variabel Kecerdasan Emosional

\begin{tabular}{|c|c|c|c|c|c|c|c|c|c|c|}
\hline & \multirow{2}{*}{ Items } & \multirow{2}{*}{ Ket. } & \multicolumn{5}{|c|}{ Kategori Jawaban } & \multirow{2}{*}{ Total } & \multirow{2}{*}{ Skor } & \multirow{2}{*}{ Mean } \\
\hline & & & SS & $\mathrm{S}$ & RG & TS & STS & & & \\
\hline \multirow{9}{*}{$\begin{array}{l}\text { Mengenali } \\
\text { emosi diri }\end{array}$} & Mengenali emosi diri & $\begin{array}{c}\text { Frek. } \\
\%\end{array}$ & $\begin{array}{c}17 \\
54,8 \%\end{array}$ & $\begin{array}{c}14 \\
45,2 \%\end{array}$ & - & - & - & $\begin{array}{c}31 \\
100 \%\end{array}$ & 141 & 4,55 \\
\hline & $\begin{array}{c}\text { Mengekspresikan } \\
\text { emosi }\end{array}$ & $\begin{array}{l}\text { Frek. } \\
\%\end{array}$ & $\begin{array}{c}13 \\
41,9 \%\end{array}$ & $\begin{array}{c}18 \\
58,1 \%\end{array}$ & - & - & - & $\begin{array}{c}31 \\
100 \%\end{array}$ & \multirow[t]{2}{*}{137} & 4,42 \\
\hline & Menyadari penyebab & Frek. & 19 & 12 & - & - & - & 31 & & \multirow{2}{*}{4,61} \\
\hline & emosi & $\%$ & $61,3 \%$ & $38,7 \%$ & - & - & - & $100 \%$ & 143 & \\
\hline & Menyadari dampak & Frek. & 12 & 19 & - & - & - & 31 & \multirow{2}{*}{136} & \multirow{2}{*}{4,39} \\
\hline & emosi & $\%$ & $38,7 \%$ & $61,3 \%$ & - & - & - & $100 \%$ & & \\
\hline & \multirow{3}{*}{ Mempengaruhi kinerja } & Frek. & 13 & 18 & - & - & - & 31 & \multirow{3}{*}{137} & \multirow{3}{*}{$\begin{array}{r}4,42 \\
4,48 \\
\end{array}$} \\
\hline & & $\%$ & $41,9 \%$ & $58,1 \%$ & $1^{-}$ & - & - & $100 \%$ & & \\
\hline & & \multicolumn{6}{|c|}{ Mean indikator mengenali emosi diri } & & & \\
\hline \multirow[t]{4}{*}{$\begin{array}{c}\text { Mengelola } \\
\text { emosi }\end{array}$} & $\begin{array}{c}\text { Tidak kehilangan } \\
\text { kontrol ketika marah }\end{array}$ & $\begin{array}{c}\text { Frek } \\
\%\end{array}$ & $\begin{array}{c}8 \\
25,8 \% \\
\end{array}$ & $\begin{array}{c}19 \\
61,3 \%\end{array}$ & $\begin{array}{c}4 \\
12,9 \%\end{array}$ & - & - & $\begin{array}{c}31 \\
100 \%\end{array}$ & 128 & 4,13 \\
\hline & $\begin{array}{l}\text { Mengatasi diri dari } \\
\text { suasana hati buruk }\end{array}$ & $\underset{\%}{\text { Frek }}$ & $\begin{array}{c}11 \\
35,5 \%\end{array}$ & $\begin{array}{c}16 \\
51,6 \%\end{array}$ & $12,9 \%$ & $\overline{-}$ & $\overline{-}$ & $\begin{array}{c}31 \\
100 \%\end{array}$ & 131 & 4,23 \\
\hline & \multirow[t]{2}{*}{ Mengatur emosi } & $\underset{\%}{\text { Frek }}$ & $\begin{array}{c}8 \\
25,8 \%\end{array}$ & $\begin{array}{c}23 \\
74,2 \%\end{array}$ & - & - & - & $\begin{array}{c}31 \\
100 \%\end{array}$ & \multirow[t]{2}{*}{132} & 4,26 \\
\hline & & & Iean indi & ator men & gelola en & & & & & 4,21 \\
\hline & Menghadapi tantangan & Frek & $\begin{array}{c}13 \\
41,9 \%\end{array}$ & $\begin{array}{c}17 \\
54,8 \%\end{array}$ & $3,2 \%$ & - & $\overline{-}$ & $\begin{array}{c}31 \\
100 \%\end{array}$ & 136 & 4,39 \\
\hline & $\begin{array}{c}\text { Menuntut gagasan } \\
\text { baru }\end{array}$ & $\begin{array}{c}\text { Frek } \\
\%\end{array}$ & $\begin{array}{c}8 \\
25,8 \%\end{array}$ & $67,7 \%$ & $6,5 \%$ & - & - & $\begin{array}{l}31 \\
100 \%\end{array}$ & 130 & 4,19 \\
\hline $\begin{array}{l}\text { Memotivast } \\
\text { diri sendiri }\end{array}$ & $\begin{array}{l}\text { Tidak mudah } \\
\text { menyerah }\end{array}$ & $\begin{array}{c}\text { Frek } \\
\%\end{array}$ & $22,6 \%$ & $\begin{array}{c}20 \\
64,5 \%\end{array}$ & $12,9 \%$ & - & - & $\begin{array}{c}31 \\
100 \%\end{array}$ & 127 & 4,10 \\
\hline & Keyalcinan berprestasi & $\underset{\%}{\text { Frek }}$ & $29,0 \%$ & $\begin{array}{c}20 \\
64,5 \%\end{array}$ & $6.5 \%$ & - & - & $\begin{array}{l}31 \\
100 \%\end{array}$ & 131 & 4,22 \\
\hline & & & $\mathrm{n}$ indikat & r memot: & vasi diri & Idiri & & & & 4,23 \\
\hline & $\begin{array}{c}\text { Merasakan perasaan } \\
\text { orang lain }\end{array}$ & $\begin{array}{c}\text { Frek } \\
\%\end{array}$ & $12,9 \%$ & $\begin{array}{c}24 \\
77,4 \%\end{array}$ & $9,7 \%$ & - & $\overline{-}$ & $\begin{array}{c}31 \\
100 \%\end{array}$ & 125 & 4,03 \\
\hline & $\begin{array}{c}\text { Mendengar keluhan } \\
\text { orang lain }\end{array}$ & $\underset{\%}{\text { Frek }}$ & $22,6 \%$ & $\begin{array}{c}21 \\
67,7 \%\end{array}$ & $9,7 \%$ & - & - & $\begin{array}{l}31 \\
100 \%\end{array}$ & 128 & 4,13 \\
\hline $\begin{array}{l}\text { Mengenali } \\
\text { emosi orang }\end{array}$ & Kebutuhan perasaan & Frek: & 2 & 27 & 2 & - & - & 31 & 124 & 4,00 \\
\hline $\begin{array}{l}\text { emosi orang } \\
\text { lain }\end{array}$ & Menuu & Frek: & $6,5 \%$ & $87,0 \%$ & $\frac{6,5 \%}{4}$ & - & $\overline{-}$ & $100 \%$ & & \\
\hline & kepercayaa & $\%$ & $16,1 \%$ & $71,0 \%$ & $12,9 \%$ & - & - & $100 \%$ & 125 & 4,03 \\
\hline & $\begin{array}{c}\text { Membaca perasaan } \\
\text { orang lain }\end{array}$ & $\underset{\%}{\text { Frek }}$ & $12,9 \%$ & $\begin{array}{c}26 \\
83,9 \%\end{array}$ & $3,2 \%$ & 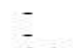 & - & $\begin{array}{c}31 \\
100 \%\end{array}$ & 127 & 4,10 \\
\hline & & Mean & ndikator & nengenal & emosio & glain & & & & 4,06 \\
\hline & $\begin{array}{l}\text { Mudah membina } \\
\text { hubungan }\end{array}$ & Frek & $\begin{array}{c}10 \\
32,3 \%\end{array}$ & $67,7 \%$ & - & - & $\overline{-}$ & $\begin{array}{c}31 \\
100 \%\end{array}$ & 134 & 4,32 \\
\hline & Menerima kritikan & $\underset{\%}{\text { Frek }}$ & $\begin{array}{c}13 \\
41,9 \%\end{array}$ & $\begin{array}{c}18 \\
58,1 \%\end{array}$ & - & - & - & $\begin{array}{c}31 \\
100 \%\end{array}$ & 137 & 4,42 \\
\hline Memb & Menerima saran & Frek: & $\begin{array}{c}11 \\
35.5 \%\end{array}$ & 19 & 1 & - & - & 31 & 134 & 4.32 \\
\hline hubur & Menjaga perasaan & Frek: & 13 & is & -270 & - & - & 31 & 137 & 4,42 \\
\hline & & $\%$ & $41,9 \%$ & $58,1 \%$ & - & - & - & $100 \%$ & 135 & 4,42 \\
\hline & & $\begin{array}{c}\text { Frek } \\
\%\end{array}$ & $\begin{array}{l}14 \\
45,2 \%\end{array}$ & $54,8 \%$ & - & - & $\overline{-}$ & $\begin{array}{c}31 \\
100 \%\end{array}$ & 138 & 4,45 \\
\hline & & & an indik & tor mem & a hul & & & & & 4,39 \\
\hline & & $\mathrm{Me}$ & n Variab & 1 Kecerd & $\operatorname{san}$ Emo & nal & & & & 4,27 \\
\hline
\end{tabular}

Dari tabel di atas dapat diketahui bahwa tanggapan responden untuk indikator mengenali emosi diri menunjukkan persentase yang mengindikasikan rata-rata responden menjawab setuju berkisar 38,7\%-61,3\%. Artinya, pegawai Kantor Kejaksaan Negeri Palu sangat setuju dengan indikator mengenali emosi diri, terutama untuk pernyataan yang berhubungan dengan "menyadari penyebab emosi” yang ditunjukkan dengan mean terbesar yaitu 4,61.

Berdasarkan tabel di atas dapat diketahui indikator yang membentuk variabel kecerdasan emosional yang memeiliki nilai mean tertinggi adalah indikator mengenali emosi diri dengan mean sebesar 4,48, sehingga dapat dikatakan bahwa indikator ini memberi kontribusi terbesar dalam membentuk variabel kecerdasan emosional pegawai Kantor Kejaksaan Negeri Palu . Sementara untuk total rata-rata keseluruhan nilai mean dari variabel kecerdasan emosioanl adalah 4,27. Dasar interprestasi nilai mean berada pada nilai 4,21-4,48, hal ini memberi makna bahwa tanggapan responden terhadap variabel kecerdasan emosional sangat baik atau sangat penting. Artinya, pegawai pada kantor kejaksaan negeri palu memiliki kecerdasan emosional yang baik, karena mereka mampu mengenali emosi diri, mengelola emosi, memotivasi diri sendiri, mengenali emosi orang lain, serta membina hubungan dengan orang lain dengan sangat baik. 


\section{Deskripsi Variabel Kinerja $(Y)$}

Kinerja adalah hasil kerja secara kualitas dan kuantitas yang dicapai oleh seorang pegawai dalam melaksanakan tugasnya sesaui dengan tanggung jawab yang diberikan kepadanya. Hasil kuesioner dari kinerja yang diajukan kepada responden memberikan gambaran bahwa kinerja pegawai Kantor Kejaksaan Negeri Palu memiliki frekuensi yang berbeda-beda, ditinjau dari indikator kinerja yang terdiri dari usaha (effort), kemampuan (abilities), dan persepsi/tugas (role/task perception). Tanggapan setiap pernyataan dari variabel kinerja dapat dilihat pada Tabel berikut ini :

Tabel 11. Tanggapam Responden Variabel Kinerja

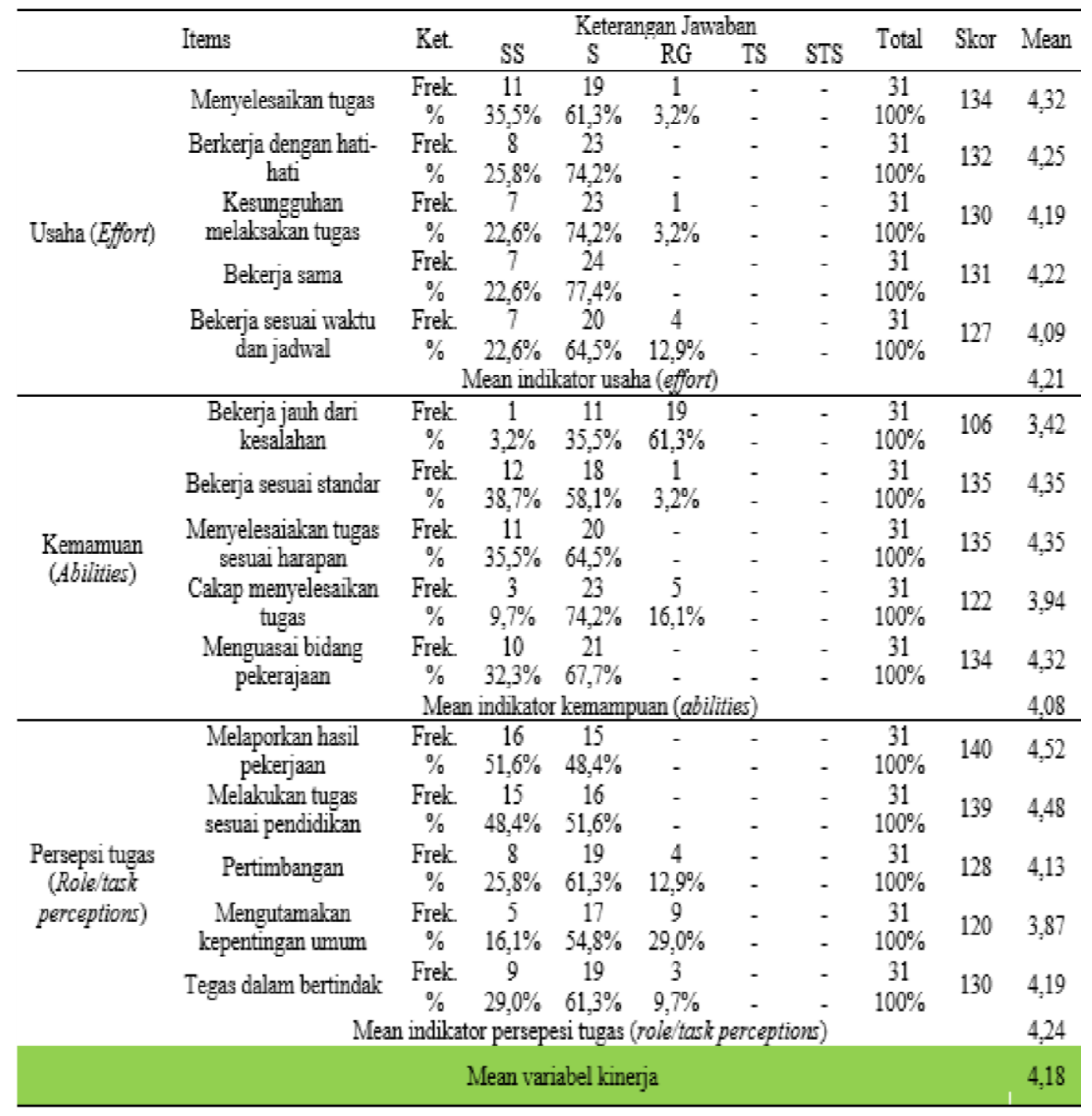

Dari tabel di atas dapat diketahui bahwa tanggapan responden untuk indikator usaha (effort) menunjukkan persentase yang mengindikasikan rata-rata responden menjawab setuju berkisar $61,3 \% 77,4 \%$. Artinya, pegawai Kantor Kejaksaan Negeri Palu setuju dengan indikator usaha (effort), terutama untuk pernyataan yang berhubungan dengan "menyelesaikan tugas" yang ditunjukkan dengan mean terbesar yaitu 4,32.

\section{Hasil Uji Regresi Linear Berganda}

Regresi linear berganda merupakan salah satu alat statistik Parametrik dengan fungsi menganalisis dan menerangkan hubungan dan pengaruh di antara dua atau lebih variabel penelitian yang berbeda identitas, melalui pengamatan pada beberapa hasil observasi di berbagai bidang kegiatan. Berkaitan dengan penelitian ini, alat analisis statistik Parametrik Regresi Linear Berganda digunakan untuk mengukur pengaruh dari variabel pendidikan dan pelatihan serta kecerdasan emosional terhadap kinerja. 
Tabel 12. Coefficients ${ }^{\mathrm{a}}$

\begin{tabular}{|c|c|c|c|c|c|c|c|}
\hline \multirow{3}{*}{ Model } & \multicolumn{2}{|c|}{ Unstandardized } & \multicolumn{2}{|l|}{ Standardized } & \multicolumn{3}{|c|}{ Collinearity Statistics } \\
\hline & \multicolumn{2}{|c|}{ Coefficients } & \multirow{2}{*}{$\frac{\text { Coefficients }}{\text { Beta }}$} & \multirow[t]{2}{*}{$\mathrm{t}$} & \multirow[t]{2}{*}{ Sig. } & & \\
\hline & $\mathrm{B}$ & Std. Error & & & & Tolerance & VIF \\
\hline (Constant) & 3.692 & .776 & & 4.756 & .000 & & \\
\hline $\mathrm{X} 1$ & .536 & .151 & .464 & 3.541 & .001 & .988 & 1.012 \\
\hline$\underline{X} 2$ & .594 & .128 & .609 & 4.654 & .000 & .988 & 1.012 \\
\hline
\end{tabular}

a. Dependent Variable: $\mathrm{Y}$

Dari hasil analisis regresi linear berganda seperti pada tabel 12 di atas, bila dimasukkan ke dalam model persamaan regresi linear berganda, maka dapat dibuat bentuk persamaan sebagai berikut:

$$
\mathrm{Y}=0,3692+0,464 \mathrm{X}_{1}+0,609 \mathrm{X}_{2}
$$

1. Nilai konstansa sebesar 0,3692 . Hal ini berartinya apabila variabel pendidikan dan pelatihan serta kecerdasan emosional dianggap konstan atau tidak ada perubahan maka besarnya variabel $\mathrm{Y}$ (Kinerja) adalah sebesar 0,3692.

2. Nilai koefisien pendidikan dan pelatihan (X1) bernilai positif sebesar 0,464. hal ini menunujukkan bahwa setiap kenaikan pendidikan dan pelatihan (X1) maka variabel kinerja (Y) akan naik sebesar 0,464 dengan asumsi bahwa variabel bebas yang lain dari model regresi adalah tetap.

3. Nilai koefisien kecerdasan emosional (X2) bernilai positif sebesar 0,609. Hal ini menunjukkan bahwa setiap kenaikan kecerdasan emosional (X2) maka variabel kinerja (Y) akan naik sebesar 0,609 dengan asumsi bahwa variabel bebas yang lain dari model regresi adalah tetap.

4. Nilai koefisien determinasi yang ditunjukan oleh nilai Multiple-R adalah sebesar 0,725, yang artinya terdapat hubungan positif secara keseluruhan dari variabel pendidikan dan pelatihan serta kecerdasan emosional terhadap kinerja pegawai sebesar 0,725 .

\section{Hasil Pengujian Hipotesis \\ Uji Simultan (Uji F)}

Berdasarkan hasil uji ANOVA (Analysis of Varians) atau $\mathrm{F}$ test diperoleh nilai $\mathrm{F}_{\text {hitung }}$ sebesar 15.506 signifikansi lebih kecil dari taraf nyata $5 \%(0,000<0,05)$. Dengan demikian (Ho) ditolak dan (Ha) diterima, karena terdapat pengaruh antara variabel $\mathrm{X}$ (pendidikan dan pelatihan serta kecerdasan emosional) secara simultan terhadap variabel Y (kinerja).

Tabel 13 Anova

\begin{tabular}{|c|c|c|c|c|c|c|}
\hline \multicolumn{7}{|c|}{ Sum of Squares } \\
\hline \multirow{2}{*}{$\frac{\text { Mode }}{1}$} & \multirow[b]{2}{*}{ Regression } & \multicolumn{2}{|c|}{ df } & Mean Square & \multirow{2}{*}{$\frac{F}{15.506}$} & \multirow{2}{*}{$\frac{\text { Sig. }}{.000^{\mathrm{b}}}$} \\
\hline & & 3.696 & 2 & 1.848 & & \\
\hline & Residual & 3.337 & 28 & .119 & & \\
\hline & Total & 7.032 & 30 & & & \\
\hline
\end{tabular}

a. Dependent Variable: Y

b. Predictors: (Constant), X2, X1

\section{Uji Parsial (Uji t)}

Berdasarkan hasil uji parsial pada tabel 13 seberapa jauh pengaruh satu variabel independen secara individual dalam menerangkan variasi variabel dependen yaitu :

1. Variabel pendidikan dan pelatihan nilai signifikansinya sebesar 0,001 . Karena angka probabilitas signifikansi < 0,05 maka Ho ditolak dan Ha diterima, dengan demikian pendidikan dan pelatihan berpengaruh signifikan terhadap kinerja pegawai. 
2. Variabel kecerdasan emosional, nilai signifikansinya sebesar 0,000. Karena angka probabilitas signifikansi < 0,05 maka Ho ditolak dan Ha diterima, dengan demikian kecerdasan emosional berpengaruh signifikan terhadap kinerja pegawai.

\section{Uji Determinasi}

R-square menunjukkan seberapa besar pengaruh variabel dalam penelitian ini secara keseluruhan. Nilai R-square dalam penelitian ini, sebesar 0,526. Hal ini menunjukkan bahwa variasi variabel pendidikan dan pelatihan serta kecerdasan emosional memberikan kontribusi sebesar 52,6\% terhadap variabel terikat Kinerja. Sedangkan 47,4 \% merupakan variabel lain yang tidak disertakan dalam penelitian ini.

\section{Pembahasan Hasil Penelitian \\ Pengaruh DIKLAT dan Kecerdasan Emosional Terhadap Kinerja}

Berdasarkan hasil observasi, penulis menyusun instrumen-instrumen penelitian yang relevan sesuai dengan kaidah-kaidah yang ada, kemudian diolah datanya sehingga hasilnya secara statistic dapat menjawab masalah-masalah yang di interprestasikan sebagai berikut:

Besarnya $F_{\text {hitung }}$ sebesar 15.506 pada signifikansi probabilitas 0,000. Sesuai dengan ketentuan, apabila nilai yang diperoleh berada di bawah 0,05 maka pengaruh variabel independen $X$ yaitu DIKLAT dan kecerdasan emosional terhadap variabel dependen Y yaitu Kinerja, dikatakan sangat kuat (signifikan).

Berdasarkan Tabel 5.17 diketahui besarnya $\mathrm{F}_{\text {hitung }}$ sebesar 15.506 pada signifikansi probablitas 0,000 ini, menunjukkan bahwa terdapat pengaruh yang signifikan dari variabel DIKLAT dan kecerdasan emosional terhadap kinerja pegawai. Besarnya pengaruh variabel independen secara keseluruhan, ditunjukkan oleh nilai R-square yaitu sebesar 0,526. Nilai tersebut dapat diartikan bahwa variabel DIKLAT dan kecerdasan emosional mampu menjelaskan kinerja sebesar 52,6\%. Sedangkan sisanya 47,4\% dipengaruhi oleh variabel lain yang tidak dimasukkan ke dalam model. Sedangkan nilai koefisien (Multiple-R) yang diperoleh sebesar 0,725, hal tersebut dapat diartikan bahwa hubungan (korelasi) variabel independen (X1 dan X2) terhadap variabel (Y) adalah sebesar 72,5\%. Dengan demikian, hipotesis pertama yang diajukan dalam penelitian ini dinyatakan terbukti kebenarannya. Hasil penelitian ini juga didukung oleh penelitian terdahulu yang dilakukan oleh :

1. I Nyoman Jaka Alit Wiratama dan Desak Ketut Sintaasih (2013), yang menyatakan bahwa variabel Kepemimpinan, DIKLAT, dan disiplin kerja berpengaruh signifikan terhadap kinerja karyawan.

2. Yossy Kanta Marga (2016), yang menyatakan bahwa variabel pelatihan, kecerdasan emosional dan budaya organisasi berpengaruh signifikan terhadap kinerja karyawan.

3. Berdasarkan hasil wawancara dengan salah satu pegawai yang berinisial $\mathrm{R}$ di bagian pembinaan, walaupun telah mengikuti diklat seringkali masih ada saja pegawai yang melakukan kesalahan dalam bekerja dan terbilang belum cakap atau belum menguasai bidang pekerjaannya sendiri.

4. Berdasarkan hasil observasi, wawancara, dan hasil penelitian yang dilakukan oleh peneliti, diketahui bahwa beberapa pegawai tidak mencapai hasil DIKLAT sesuai dengan harapan sehingga hal ini berdampak pada sulitnya mengelola emosional dalam bekerja. Untuk itu pihak Kantor Kejaksaan Negeri Palu memberikan inovasi pada saat DIKLAT, misalnya memberikan materi-materi yang lebih komukatif dan atraktif, sehingga pencapaian yang diharapkan dapat tercapai dengan maksimal dan dapat meningkatkan kecerdasan emosional.

\section{Pengaruh Pendidikan dan Pelatihan terhadap Kinerja}

Berdasarkan hasil uji parsial, diketahui pendidikan dan pelatihan nilai signifikansinya 0,001 . Karena angka probabilita signifikansinya $<0,05$ sehingga pendidikan dan pelatihan berpengaruh positif dan signifikan terhadap kinerja diterima. Hal ini berarti bahwa tinggi atau rendahnya kinerja ditentukan secara langsung oleh tinggi atau rendahnya pengaruh pendidikan dan pelatihan. Semakin baik sistem pelaksanaan pendidikan dan pelatihan, maka kinerja akan semakin tinggi.

Hasil penelitian ini juga didukung oleh penelitian yang dilakukan oleh Soejaya (2013), yang menyatakan bahwa terdapat hubungan yang positif dan signifikan antara pendidikan dan pelatihan dengan kinerja karyawan pada Joint Operating Body Pertamina-Petrochina East Java . 
Berdasarkan hasil wawancara, salah satu alasan kurang baiknya kinerja disebabkan oleh kurangnya keterampilan instruktur dalam memberikan pemahaman mengenai materi diklat, sehingga para pegawai tidak dapat memahami materi diklat dengan baik.

Untuk itu pihak Kantor Kejaksaan Negeri Palu memperhatikan lebih detail pelaksanaan program diklat. Seperti siapa saja pemateri, jam pelaksaan penerimaan materi diklat, serta metode diklat yang mudah dimengerti oleh peserta diklat sehingga dapat mencapai hasil yang diharapkan demi memaksimalkan kinerjanya.

\section{Pengaruh Kecerdasan Emosional terhadap Kinerja}

Berdasarkan hasil uji parsial, diketahui variabel kecerdasan emosional nilai signifikansinya sebesar 0,000. Karena angka probabilitas signifikansi $<0,05$ sehingga kecerdasan emosional berpengaruh terhadap kinerja diterima. Dari nilai signifikansi yang diperoleh, dapat disimpulkan bahwa variabel kecerdasan emosional mempunyai pengaruh yang signifikan terhadap kinerja pegawai pada Kantor Kejaksaan Negeri Palu.

Hasil penelitian ini juga didukung oleh penelitian yang dilakukan oleh Marga (2016), yang menyatakan bahwa terdapat hubungan yang positif dan signifikan antara kecerdasan emosional dengan kinerja karyawan pada PT. Pelayaran Tempuran Emas Surabaya.

Teori Goleman (2015) yang menyatakan bahwa 80\% kesuksesan seseorang dipengaruhi kecerdasan lain seperti kecerdasan emosional, juga berlaku pada Pegawai Kantor Kejaksaan Negeri Palu Sulawesi Tengah.

Hasil wawancara dengan salah satu pegawai honorer inisial N)* menunjukkan bahwa ada beberapa pegawai yang tidak dapat mengelola emosinya dengan baik, misalnya ketika pegawai diberikan pekerjaan yang mendesak atau tugas yang bukan bidangnya, sehingga pegawai tersebut seringkali tidak menyelesaikan tugas itu dengan suasana hati yang kurang baik karena menurutnya memberatkan dan menimbulkan rasa jengkel akan tetapi sesungguhnya pegawai tersebut tetap dapat menyelesaikan pekerjaannya dengan baik.

\section{KESIMPULAN DAN SARAN Kesimpulan}

Setelah dilakukan penelitian tentang pengaruh pendidikan dan pelatihan serta kecerdasan emosional terhadap kinerja pegawai Kantor Kejaksaan Negeri Palu dengan menggunakan analisis regresi bergandan, maka dapat disimpulkan sebagai berikut :

1. Pendidikan dan Pelatihan (X1) serta Kecerdasan Emosional (X2), secara simultan berpengaruh signfikan (positif) terhadap Kinerja (Y) pada Kantor Kejaksaan Negeri Palu Sulawesi Tengah. Hal ini dibuktikan dengan hasil uji $\mathrm{F}$ yang sangat signifikan pada tingkat kepercayaan $99 \%$.

2. Pendidikan dan Pelatihan (X1) secara parsial berpengaruh signifikan (positif) terhadap kinerja (Y) pada Kantor Kejaksaan Negeri Palu Sulawesi Tengah. Hal ini dibuktikan dengan hasil uji F yang sangat signifikan pada tingkat kepercayaan $98,9 \%$.

3. Kecerdasan Emosional (X2) secara parsial berpengaruh signifikan (positif) terhadap kinerja (Y) pada Kantor Kejaksaan Negeri Palu Sulawesi Tengah. Hal ini dibuktikan dengan hasil uji F yang sangat signifikan $99 \%$.

\section{Saran}

Berdasarkan hasil kesimpulan dari analisa yang telah dilakukan, maka saran-saran yang dapat diajukan pada Kantor Kejaksaan Negeri Palu Sulawesi Tengah dalam upaya meningkatkan kinerja pegawai adalah sebagai berikut:

1. Hasil positif yang signifikan pada variabel pendidikan dan pelatihan terhadap kinerja, menujukkan bahwa semakin sering pegawai mengikuti pendidikan dan pelatihan maka kinerjanya akan semakin menigkat. Untuk itu disarankan kepada pihak Kejaksaan Negeri Palu agar senantiasa mempertahankan program diklat sebagai sebuah agenda yang penting dalam upaya peningkatan kinerja pegawai.

2. Hasil positif yang signifikan pada variabel kecerdasan emosional terhadap kinerja, menunjukkan bahwa semakin pandai pegawai kantor kejaksaan negeri palu mengenali emosi diri, mengelola emosi, memotivasi diri sendiri, mengenali emosi orang lain dan membina hubungan dengan orang 
lain maka kineja pegawai akan semakin meningkat. Untuk itu disarankan agar para pegawai senantiasa menjalin kearaban dan juga melakukan sharring agar tercipta keterbukaan yang dapat mengungkapkan kendala-kendala pegawai dalam melaksanakan tugas-tugasnya.

\section{REFERENSI}

Goleman, D. (2007). Working With Emotional Intelligence (terjemahan). Jakarta: PT. Gramedia Pustaka Utama..

Goleman, D. (2015). Emotional Inteliigence, (terjemahan). Jakarta: PT. Gramedia Pustaka Utama.

Arep, I. \& Tanjung, H. (2002). Manajemen Sumber Daya Manusia. Cetakan Pertama April

Marlia, E. (2007). Pengaruh Program Pendidikan dan Pelatihan Terhadap Prestasi Kerja Karyawan Pada PT. Inti (Persero) Bandung. Skripsi

Mangkunegara, A. P. (2013). Manajemen Sumber Daya Manusia Perusahaan. Cetakan ke sebelas. Bandung: PT Remaja Rosdakarya.

Marga, Y. K. (2016). Pengaruh Pelatihan, Kecerdasan Emosional, dan Budaya Organisasi Terhadap Kinerja Karyawan Pada PT Pelayaran Tempuran Emas Surabaya. E-Jurnal Manajemen Kinerja, 2(1).

Satori, D. (2007). Profesi Keguruan. Jakarta: Universitas Terbuka (UT).

Soejaya, R. E. (2013). Peran Pendidikan Dan Pelatihan, Budaya Organisasi, Motivasi Serta Disiplin Kerja Terhadap Kinerja Pegawai Badan Kesatuan Bangsa, Politik Dan Perlindungan Masyarakat Kabupaten Kediri. Jurnal Otonomi, 13(1).

Sofyandi, H. (2008). Management Somber Daya Manusia. Graha Ilmu.

Sugiyono. (2009). Metode Penelitian Bisnis. Bandung: Alfabeta.

Umar, H. (2002). Metode Riset Bisnis. Jakarta: Gramedia Pustaka Utama. 